\title{
Diurnal Variation in the Activities of Isocitrate and Glucose-6-Phosphate Dehydrogenases in Gactus Phylloclades
}

Remarkable diurnal variations in cactus phylloclades have been reported in the activities of various enzymes $^{1-5}$, protein and citric acid content ${ }^{3}$. In view of the crassulacean type acid metabolism and succulent nature of the cactus phylloclades, rhythmic variation in enzymic activities could provide important correlations with the metabolism in this plant. The results in the present communication describe diurnal variations in the activities of isocitrate dehydrogenase [EC 1.1.1.42 threo-DS-isocitrate: NADP oxidoreductase] and glucose6-phosphate dehydrogenase [EC 1.1.1.49 D-glucose-6phosphate: NADP oxidoreductase] in cactus Nopalea dejecta, plant grown under natural conditions of light and darkness.

Materials and methods. Details of sampling and homogenization procedures were those described earlier ${ }^{3}$. The activities of isocitrate and glucose-6-phosphate dehydrogenases were estimated as described by ScotT et al. ${ }^{6}$ at limiting concentrations of enzyme. The reaction was run for $5 \mathrm{~min}$ at $30^{\circ} \mathrm{C}$ and terminated by the addition of ethanol and sodium sulfate ${ }^{3}$. A unit of enzyme caused the reduction of $1 \mu$ mole NADP per min under the assay conditions. For the best evaluation of diurnal variation, the activities were expressed on the basis of fresh weight of the tissue ${ }^{2}$

Results. Diurnal activities of isocitrate and glucose-6phosphate dehydrogenases are described in the Table. The maximum activity of isocitrate dehydrogenase was at $16.00 \mathrm{~h}$ and the minimum at $08.00 \mathrm{~h}$, the former being $200 \%$ higher. In the case of glucose-6-phosphate dehydrogenase, maximum activity was, however, at $08.00 \mathrm{~h}$ and the minimum at midnight with a variation of $300 \%$.

In order to test whether the spectrophotometric estimations of these dehydrogenases were affected by the presence of NADPH oxidizing system, the reduced coenzyme was incubated with cactus enzyme. No oxidizing system was found to be operative under the test conditions.

Inspite of the fact that, in sampling, 15-24 phylloclades were taken at each operation, the biological variation and the statistical reproducibility was ascertained by making 5 separate estimations. In each case the pattern of variation was reproducible; there were little difference in the magnitude of variation. Statistical analysis of the results was found to be highly significant $(p<0.01)$.

Diurnal activities of isocitrate and glucose-6-phosphate dehydro genases

Collection

of sample
Enzyme activity

(unit/g fresh weight)

Isocitrate

dehydrogenase
To evaluate the effect of some endogenous metabolic effectors, the activities were estimated on mixed homogenates. Enzyme preparations of maximum and minimum activity were mixed equally and simultaneous estimations on mixed and individual preparations were made. It was observed that the activities of both the enzymes were inhibited on mixing. The magnitude of inhibition was respectively 15 and $20 \%$ for isocitrate and glucose6-phosphate dehydrogenases.

Discussion. Like other enzymes of the Krebs cycle ${ }^{3}$, isocitrate dehydrogenase also showed maximum activity in the day time $(16.00 \mathrm{~h})$. Diurnal variation in organic acid content is known for malate and citrate pools in succulents ${ }^{7}$. The diurnal variation in the activity of isocitrate dehydrogenase suggests its bearing on the acid metabolism at the citrate pool. The diurnal variation observed in glucose-6-phosphate dehydrogenase, a key enzyme of pentose phosphate pathway, is of considerable significance. RICHTER and PIRson ${ }^{8}$ found no rhythm in glucose-6-phosphate dehydrogenase activity in alternating light and darkness in Hydrodictyon. According to BRADBEER et al. ${ }^{9}$, phosphoenolpyruvate, the main suggested $\mathrm{CO}_{2}$-acceptor in the dark acidification, is formed from 3-phosphoglycerate by carboxylation of ribulose diphosphate. The increased glucose-6-phosphate dehydrogenase activity observed in the day time in cactus phylloclades would constitute a means of providing the $\mathrm{CO}_{\mathrm{z}}$-acceptor for dark acidification.

KHAN and SANwAL ${ }^{3}$ have discussed the factors responsible for the diurnal variations of enzymes, such as light, darkness, synthesis and degradation of enzyme proteins, as well as alterations in the level of metabolic effectors. The data of mixed homogenates are consistant with the view that a small part of the enzyme activity variation was due to cyclic elaboration of inhibitor(s) molecules ${ }^{10}$

Zusammenfassung. Die Aktivitäten der Isocitrat- und Glukose-6-P-Dehydrogenasen erreichen in Kakteen ( $\mathrm{No}$ palea dejecta) zu verschiedenen Tageszeiten ihr Maximum.

\section{A. A. Khan 11 and G. G, Sanwal}

Department of Biochemistry, University of Lucknow, Lucknow (U.P., India), 25 July 1970.

1 G. G. Sanwal and P. S. Krishnan, Nature, Lond. 188, 664 (1960). ${ }^{2}$ S. K. Mukerji, G. G. Sanwal and P. S. Krishnan, Ind. J. Biochem. 1, 36 (1964).

A. A. Khan and G. G. Sanwal, Ind. J. Biochem. 2, 207 (1965).

4 S. K. MukER Ji, Ind. J. Biochem. 5, 62 (1968).

5 A. A. Khan, C. P. Tewari, P. S. Krishnan and G. G. Sanwal, Phytochemistry, 9, 2097 (1970).

- K. J. ScotT, J. S. Craigie and R. M. Smillie, Plant Physiol. 39,323 (1964)

7 S. L. Ranson and M. Thomas, Ann. Rev, P1. Physiol, 11, 81 (1960).

${ }^{8}$ G. Richter and A. Pirson, Flora, Jena 744, 562 (1957).

- J. W. Bradbeer, S. L. Ranson and M. L. Stiller, Plant Physiol. $33,66(1958)$.

10 The authors wish to thank the Council of Scientific and Industrial Research, New Dehli, for financial assistance.

11 Central Research Laboratory, Antibiotics Plant, Virbhadra (U.P., India). 